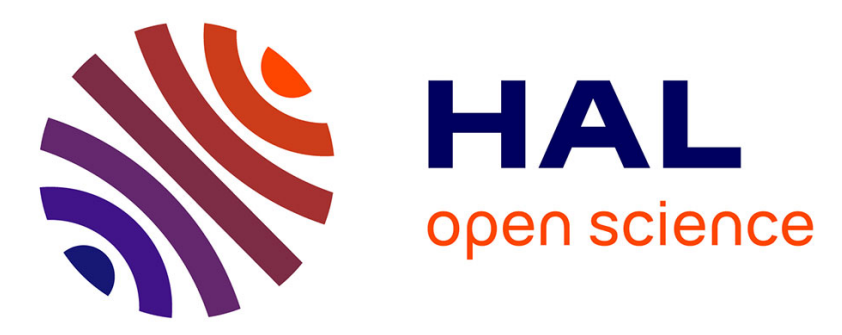

\title{
Energy and Exergy Analyses of Fluidized-Bed Municipal Solid Waste Air Gasification
}

Yuanjun Tang, Jun Dong, Yong Chi, Zhaozhi Zhou, Mingjiang Ni

\section{To cite this version:}

Yuanjun Tang, Jun Dong, Yong Chi, Zhaozhi Zhou, Mingjiang Ni. Energy and Exergy Analyses of Fluidized-Bed Municipal Solid Waste Air Gasification. Energy \& Fuels, 2016, 30 (9), p. 7629-7637. 10.1021/acs.energyfuels.6b01418 . hal-01609018

\section{HAL Id: hal-01609018 https://hal.science/hal-01609018}

Submitted on 8 Jan 2019

HAL is a multi-disciplinary open access archive for the deposit and dissemination of scientific research documents, whether they are published or not. The documents may come from teaching and research institutions in France or abroad, or from public or private research centers.
L'archive ouverte pluridisciplinaire HAL, est destinée au dépôt et à la diffusion de documents scientifiques de niveau recherche, publiés ou non, émanant des établissements d'enseignement et de recherche français ou étrangers, des laboratoires publics ou privés. 


\title{
Energy and Exergy Analyses of Fluidized-Bed Municipal Solid Waste Air Gasification
}

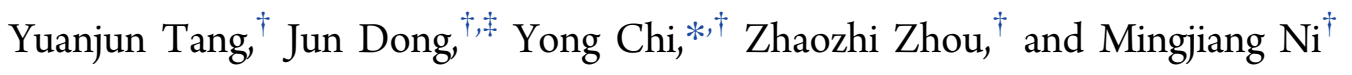 \\ ${ }^{\dagger}$ State Key Laboratory of Clean Energy Utilization, Zhejiang University, Hangzhou, Zhejiang 310027, People’s Republic of China \\ ¥Centre de Recherche d'Albi en génie des Procédés des Solides Divisés, de l'Énergie et de l'Environnement (RAPSODEE), UMR \\ CNRS 5302, Mines Albi, Université de Toulouse, Campus Jarlard, F-81013 Albi Cedex 09, France
}

\begin{abstract}
With the aim of optimizing gasification systems, air gasification using simulated municipal solid waste is experimentally investigated in a fluidized-bed reactor. Process parameters considered include equivalence ratio (ER) and temperature. On the basis of the experimental results, energy and exergy analyses are performed to assess the thermodynamic quality. Results reveal that the energy and exergy contents of the produced gas increase first with rising temperature and then decline when the temperature exceeds $650{ }^{\circ} \mathrm{C}$. With regard to the ER, a similar tendency is observed with a peak value at an ER of 0.4. The energy content of the produced gas is much higher than its exergy content as a result of the remarkable difference between physical energy and exergy contents of sensible heat. The maximum chemical energy efficiency, total energy efficiency, chemical exergy efficiency, and total exergy efficiency of the products at the gasifier exit are attained at an ER of 0.4 and a temperature of $650{ }^{\circ} \mathrm{C}$, with values of $49.73,64.05,47.14$, and $51.33 \%$, respectively. The total exergy efficiency is suggested as an effective parameter to evaluate the properties of gasification-based thermal systems, because it expresses the availability of the products from the "first-step" gasifier for subsequent conversion.
\end{abstract}

\section{INTRODUCTION}

The vast growth of urbanization has resulted in an increasing generation of municipal solid waste (MSW) worldwide. Thermal treatment has been proven to be a promising wasteto-energy route adopted by various countries and regions. ${ }^{1-3}$ MSW incineration, for instance, can achieve both waste volume reduction and energy recovery by thoroughly destroying combustible components. ${ }^{4}$ However, toxic emissions, especially dioxins and heavy metals, and harmful residues have caused serious environmental problems and adverse health impacts to humans. ${ }^{5}$ On the other hand, the energy efficiency of a MSW incineration plant is ca. $20 \%$ only, much lower than that of a coal-fired power plant. As a consequence, MSW incineration has received more and more resistance from the general public.

In the past few decades, novel thermal technologies applying gasification have emerged as an attractive solution for MSW treatment. ${ }^{6,7}$ MSW gasification is defined as the thermochemical conversion of MSW to useful products (i.e., raw gas, char, and tar) through partial oxidization. In comparison to "singlestep" waste incineration, gasification technologies are "twostep" oxidation systems and are beneficial to reduce dioxins and $\mathrm{NO}_{x}$ emissions as a result of the reducing atmosphere during gasification. The energy vectors acquired in the "first-step" could be used in different approaches, which offer the possibility to establish a more energy-efficient system in combination with subsequent conversion. In recent years, several studies have focused on the characteristics of MSW gasification. ${ }^{8,9}$ Zheng et al. ${ }^{10}$ studied MSW gasification at various temperatures and equivalence ratios (ERs), observing that ER and temperature are the dominant factors for gasification. Xiao et al. ${ }^{11}$ investigated the gasification of five typical organic waste components, with results indicating that feedstock composition determines the quality of the output product streams. Nevertheless, although development on waste gasification attracts more and more attention, commercial applications have not been achieved in China. Therefore, it is essential to thoroughly investigate waste gasification, with special regard to Chinese local conditions.

To better reflect the performance of waste gasification, energy and exergy analyses are well-proven and effective thermodynamic methods to evaluate thermal processes. ${ }^{12,13}$ Energy analysis is based on the first law of thermodynamics, taking into account the energy content of all input and output streams. The core concept is that energy cannot be destroyed or created, because energy flows are considered to be continuous and obey the conservation law. ${ }^{14}$ Regardless of forms, energy is regarded to be equivalent and only its quantity is taken into account. However, according to the second law of thermodynamics, the quality of energy degrades through irreversible conversion. Hence, energy analysis alone may cause misunderstandings when applied to describe thermal systems. For example, the energy (entropy) value of gases is maintained unchanged when it is adiabatically throttled, whereas the available part of energy reduces. ${ }^{15}$ Realizing this fact, the exergy theory is put forward in this work to incorporate both quantity and quality of energy. Exergy is defined as the maximum amount of work that can be obtained from a system when it comes to equilibrium with its reference environment. ${ }^{12,16}$ Exergy analysis uses the conservation of mass and energy principles together with the second law of thermodynamics, and it can also estimate internal energy losses of systems and identify losses as a result of irreversibility. ${ }^{17}$ 
Table 1. Properties of S-MSW

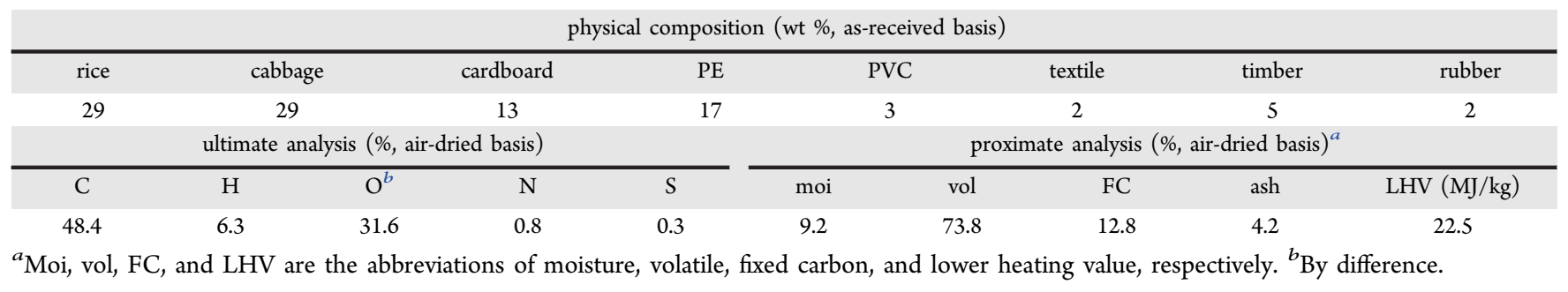

Thus far, energy and exergy analyses have been successfully conducted to assess the thermodynamic performance of MSW management systems or to improve the system efficiency. Pellegrini and de Oliveira ${ }^{18}$ evaluated the process irreversibility associated with sugar cane bagasse gasification using exergy analysis. Kaushik et al. ${ }^{19}$ critically reviewed the use of energy and exergy analyses on thermal power plants, stating that energy and exergy analyses can help with the understanding of the performance of thermal systems and identify possible efficiency improvements. However, a paralleled and comprehensive assessment using both energy and exergy analyses for the waste gasification process is quite lacking. ${ }^{20,21}$ Therefore, it is meaningful to conduct a thorough energy and exergy evaluation, to better understand the thermodynamic performance of gasification-based MSW to the energy system and to identify and improve the weak link of the system.

Accordingly, the main objective of the present work is to evaluate the characteristics of MSW gasification with regard to local conditions as well as to conduct comprehensive energy and exergy analyses on its thermodynamic performance to find a more suitable efficiency evaluation parameter. Product mass and energy/exergy distribution, energy and exergy contents of produced gas, and process efficiencies are all taken into consideration. The obtained results could be valuable in the future for decision-makers to determine a better waste treatment and energy recovery strategy via gasification.

\section{MATERIALS AND METHODS}

2.1. Experiments. To ensure the consistence of feedstock among tests, a homogeneous, simulated municipal solid waste (S-MSW) is used. It is prepared according to the statistical waste composition as established in Hangzhou, China. ${ }^{22}$ The S-MSW physical composition and the ultimate and proximate analysis information are shown in Table 1.

A schematic diagram of the experimental system is exhibited in Figure 1. It is a lab-scale electrically heated fluidized-bed reactor. The system consists of a main reaction chamber, a gas supply system, a feeder, a gas-cleaning system, and a heating and temperaturemeasuring system. The main reaction chamber is made of thermostable ceramics, which is $60 \mathrm{~mm}$ in inner diameter and $1100 \mathrm{~mm}$ in height. During the experiments, the temperature profile in the reactor is recorded by three $\mathrm{K}$-type thermocouples equipped at the top, middle, and bottom of the furnace. More detailed information on the experimental apparatus is available in our previous work..$^{23}$

For all of the experimental runs, the fluidizing gas flow rate is kept constant $\left(U_{\mathrm{m}}=0.183 \mathrm{~N} \mathrm{~m} \mathrm{~s}^{-1}=1.5 \mathrm{U}_{\mathrm{mf}}\right)$. During each test, product yields and gas composition are recorded and analyzed. After the experiment reaches stable operating conditions, gas samples are taken every $10 \mathrm{~min}$, using gas bags. Dry gas yield $\left(\mathrm{N} \mathrm{m}^{3} \mathrm{~kg}^{-1}\right.$ of S-MSW) is quantified on the basis of a $\mathrm{N}_{2}$ balance, and the gas composition is determined by gas chromatographic analysis (micro GC-490 analyzer, Agilent). Tar is trapped in successive condensers and then weighed. Fly ash is obtained from the cyclone separator. Char is collected from the bottom of the furnace after each test. The heating value of the feedstock and products is detected according to the National Standard

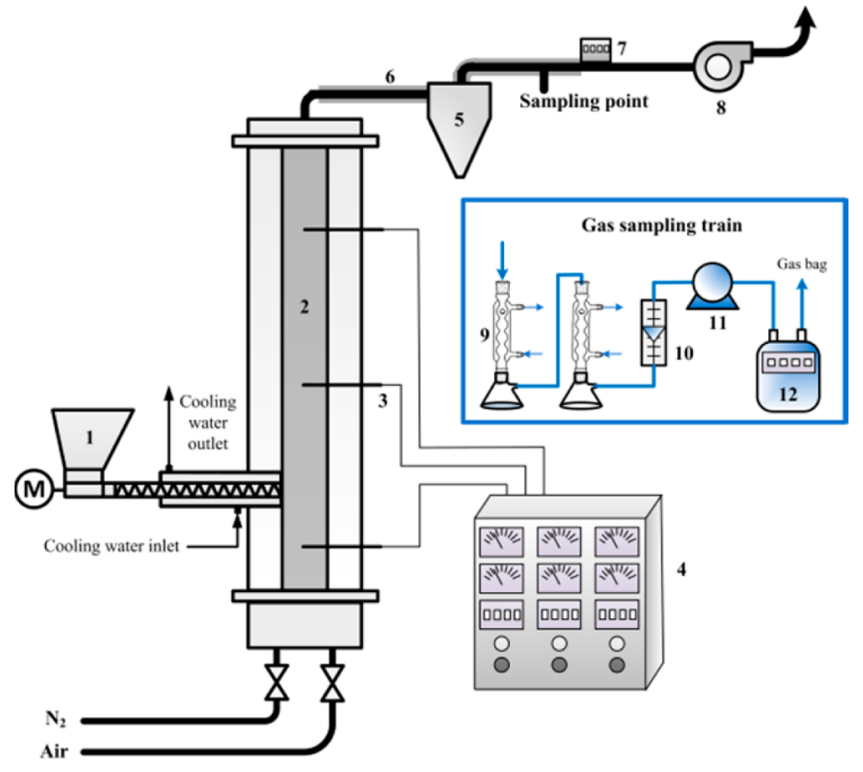

Figure 1. Schematic diagram of the experimental system: (1) screw feeder, (2) reaction chamber, (3) thermocouples, (4) controller, (5) cyclone separator, (6) heating tape, (7) temperature measurement, (8) induced draft fan, (9) serpentine condenser, (10) rotor flow meter, (11) vacuum pump, and (12) accumulative flow meter.

GB/T 213-2008. For each test condition, experiments are replicated 3 times to guarantee the reliability of the data and average values are used in the present study.

2.2. Analytical Methods for Energy and Exergy Analyses. Data obtained from gasification experiments are used to perform the energy and exergy analyses. A diagram of the gasification process with input and output streams is shown in Figure 2. The calculation methods are described in detail as follows.

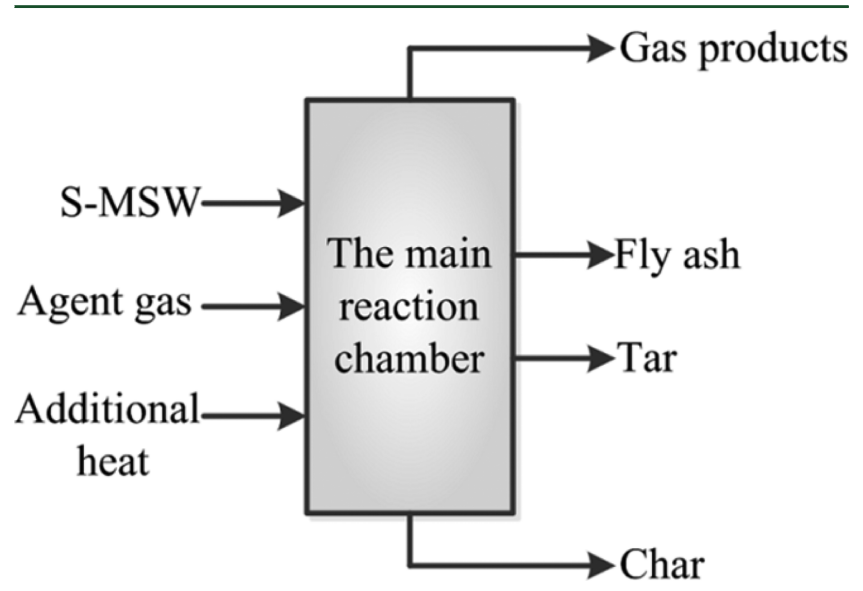

Figure 2. Input and output streams of gasification experiments. 
Table 2. Coefficients of Constant Pressure Specific Heat Capacity and Standard Chemical Exergy of Some Gas Components

\begin{tabular}{|c|c|c|c|c|c|c|c|}
\hline gas & $a$ & $b$ & $c$ & $d$ & $f$ & temperature range $(\mathrm{K})$ & $e_{\mathrm{ch}}^{0}(\mathrm{~kJ} / \mathrm{mol})^{a}$ \\
\hline $\mathrm{H}_{2}$ & 33.07 & -11.36 & 11.43 & -2.77 & -0.16 & $298-1000$ & 236.1 \\
\hline $\mathrm{H}_{2}$ & 18.56 & 12.25 & -2.86 & 0.27 & 1.98 & $1000-2500$ & 236.1 \\
\hline $\mathrm{CO}_{2}$ & 25.00 & 55.19 & -33.69 & 7.95 & -0.14 & $298-1200$ & 19.87 \\
\hline $\mathrm{CO}$ & 25.57 & 6.10 & 4.05 & -2.67 & 0.13 & $298-1300$ & 275.10 \\
\hline $\mathrm{O}_{2}$ & 30.03 & 8.77 & -3.99 & 0.79 & -0.74 & $700-2000$ & 3.97 \\
\hline $\mathrm{CH}_{4}$ & -0.70 & 108.48 & -42.51 & 5.86 & 0.68 & $298-1300$ & 831.65 \\
\hline $\mathrm{N}_{2}$ & 19.51 & 19.89 & -8.60 & 1.37 & 0.53 & $500-2000$ & 0.69 \\
\hline $\mathrm{C}_{2} \mathrm{H}_{4}$ & -6.39 & 184.40 & -112.97 & 28.50 & 0.32 & $298-1200$ & 1361.1 \\
\hline $\mathrm{C}_{2} \mathrm{H}_{2}$ & 40.69 & 40.73 & -16.18 & 3.67 & -0.66 & $298-1100$ & 1265.8 \\
\hline $\mathrm{C}_{2} \mathrm{H}_{2}$ & 67.47 & 11.75 & -2.02 & 0.14 & -9.81 & $1100-6000$ & 1265.8 \\
\hline $\mathrm{C}_{2} \mathrm{H}_{6}{ }^{b}$ & & & & & & & 1495.84 \\
\hline
\end{tabular}

${ }^{a}$ The standard chemical exergy data of produced gas components is obtained from ref $24 .{ }^{b}$ Coefficient data for $\mathrm{C}_{2} \mathrm{H}_{6}$ gas is not available from the NIST database; therefore, its enthalpy and entropy values are derived from the CRC Handbook of Chemistry and Physics. ${ }^{41}$

According to the first law of thermodynamics, energy obeys the conservation law. Therefore, the energy balance can be described according to Figure 2 as

$$
\sum E_{\text {in }}=\sum E_{\text {out }}+\sum E_{\text {loss }}
$$

with

$$
\begin{aligned}
& \sum E_{\text {in }}=E_{\mathrm{S}-\mathrm{MSW}}+E_{\text {agent }}+E_{\text {addit }} \\
& \sum E_{\text {out }}=E_{\text {gas }}+E_{\text {tar }}+E_{\text {water }}+E_{\text {char }}+E_{\mathrm{fa}}
\end{aligned}
$$

where $\sum E_{\text {in }}$ and $\sum E_{\text {out }}$ represent the energy contents of input and output streams, respectively, $E_{\text {loss }}$ stands for the energy loss during the experiment, and the subscript items, i.e., agent, addit, gas, and fa, stand for the agent gas, additional heat, gas, and fly ash, respectively. An additional heat supply is excluded from the present study as a result of measurement limitations.

As aforementioned, exergy represents the maximum potential work of a system when it equilibrates with the reference environment. To perform the exergy analysis, the reference environment state (dead state) is defined with a reference temperature $\left(T_{0}\right)$ of $298.15 \mathrm{~K}$ and a reference pressure $\left(P_{0}\right)$ of $1 \mathrm{~atm}$ in this work. ${ }^{24}$

As a result of the process irreversibility, exergy is not conservative and internal exergy losses are unavoidable. Therefore, the exergy balance can be described as

$$
\sum e_{\text {in }}=\sum e_{\text {out }}+\sum e_{\text {loss }}+I
$$

with

$$
\begin{aligned}
& \sum e_{\mathrm{in}}=e_{\mathrm{S}-\mathrm{MSW}}+\mathrm{e}_{\text {agent }}+\mathrm{e}_{\mathrm{addit}} \\
& \sum e_{\mathrm{out}}=e_{\mathrm{gas}}+e_{\mathrm{tar}}+e_{\mathrm{water}}+e_{\mathrm{char}}+e_{\mathrm{fa}}
\end{aligned}
$$

where $\sum e_{\text {in }}$ and $\sum e_{\text {out }}$ represent the exergy contents of input and output streams, respectively, $e_{\text {loss }}$ stands for the external exergy losses caused by emissions, and $I$ stands for the internal exergy destruction (or irreversibility).

Generally, kinetic exergy and potential exergy values are relatively small and, thus, negligible in the analysis. ${ }^{25}$ Therefore, the exergy of a material flow $(e)$ is determined by its chemical composition (chemical exergy, $\left.e_{\mathrm{ch}}\right)$ and physical state (physical exergy, $e_{\mathrm{ph}}$ )

$$
e=e_{\mathrm{ch}}+e_{\mathrm{ph}}
$$

The physical exergy of a gas flow is calculated as

$$
e_{\mathrm{ph}}=\sum\left[\left(h-h_{0}\right)-T_{0}\left(s-s_{0}\right)\right]
$$

where

$$
h-h_{0}=\int_{T_{0}}^{T} c_{\mathrm{p}} \mathrm{d} T
$$

$$
s-s_{0}=\int_{T_{0}}^{T} \frac{c_{\mathrm{p}}}{T} \mathrm{~d} T-R \ln \frac{P}{P_{0}}
$$

where $h$ and $s$ are the enthalpy and entropy of gas species under a given condition, respectively, $h_{0}$ and $s_{0}$ represent the values under the dead state, $c_{\mathrm{p}}$ is the constant pressure specific heat capacity, and $R$ is the universal gas constant $\left(8.314472 \mathrm{~J} \mathrm{~mol}^{-1} \mathrm{~K}^{-1}\right)$.

The constant pressure specific heat capacity $\left(c_{\mathrm{p}}\right)$ of gas components is calculated with the Shomate equation using data from the National Institute of Standards and Technology (NIST) database $\mathrm{e}^{26}$

$$
c_{\mathrm{p}}=a+b T+c T^{2}+d T^{3}+f / T^{2}
$$

where $T=$ temperature $(\mathrm{K}) / 1000$ and $a, b, c, d$, and $f$ are coefficients of constant pressure specific heat capacity and presented in Table $2 .{ }^{26}$

The chemical exergy of a gas flow is caused by the difference of its chemical composition and concentration with the reference environment as

$$
e_{\mathrm{ch}}=\sum y_{i} e_{\mathrm{ch}, i}^{0}+T_{0} R \sum y_{i} \ln y_{i}
$$

where $y_{i}$ and $e_{\mathrm{ch}, i}^{0}$ are the mole fraction and standard chemical exergy of the $i$ th gas component, respectively. The standard chemical exergy of produced gas components is also presented in Table 2.

Accordingly, the total exergy content of the gas mixtures can be determined by

$$
\begin{aligned}
e_{\mathrm{gas}}^{\mathrm{tot}}= & \sum y_{i}\left[\left(h-h_{0}\right)_{i}-T_{0}\left(s-s_{0}\right)_{i}\right] \\
& +\left(\sum y_{i} e_{\mathrm{ch}, i}^{0}+T_{0} R \sum y_{i} \ln y_{i}\right)
\end{aligned}
$$

The physical exergy of solid and liquid products is relatively small. Therefore, modeled compounds of silicone dioxide, graphite, and crude oil are selected for the calculation of the physical energy and exergy of char, fly ash, and tar, respectively.

The chemical exergy of solid materials is estimated on the basis of its lower heating value as

$$
\mathrm{e}_{\text {solid }}=\beta_{\text {solid }} \mathrm{LHV}_{\text {solid }}
$$

where $e_{\text {solid }}$ and $\mathrm{LHV}_{\text {solid }}$ represent the exergy value and lower heating value of solid materials, respectively, and $\beta_{\text {solid }}$ is the correlation factor of solid material according to its elementary composition as ${ }^{27}$

$$
\begin{aligned}
& \beta_{\text {solid }}=(1.0412+0.2160 H / C-0.24990 / C(1+0.7884 H / C) \\
& \quad+0.0450 N / C) /(1-0.3034 O / C) \quad(O / C \leq 2.67)
\end{aligned}
$$

where $H, C, O$, and $N$ are the mass fractions of hydrogen, carbon, oxygen, and nitrogen in the solid material, respectively.

The chemical exergy of tar can be obtained in the same way, while the correlation factor $\beta_{1}$ of liquid material is estimated as

$$
\beta_{1}=1.0401+0.1728 H / C+0.0432 O / C
$$



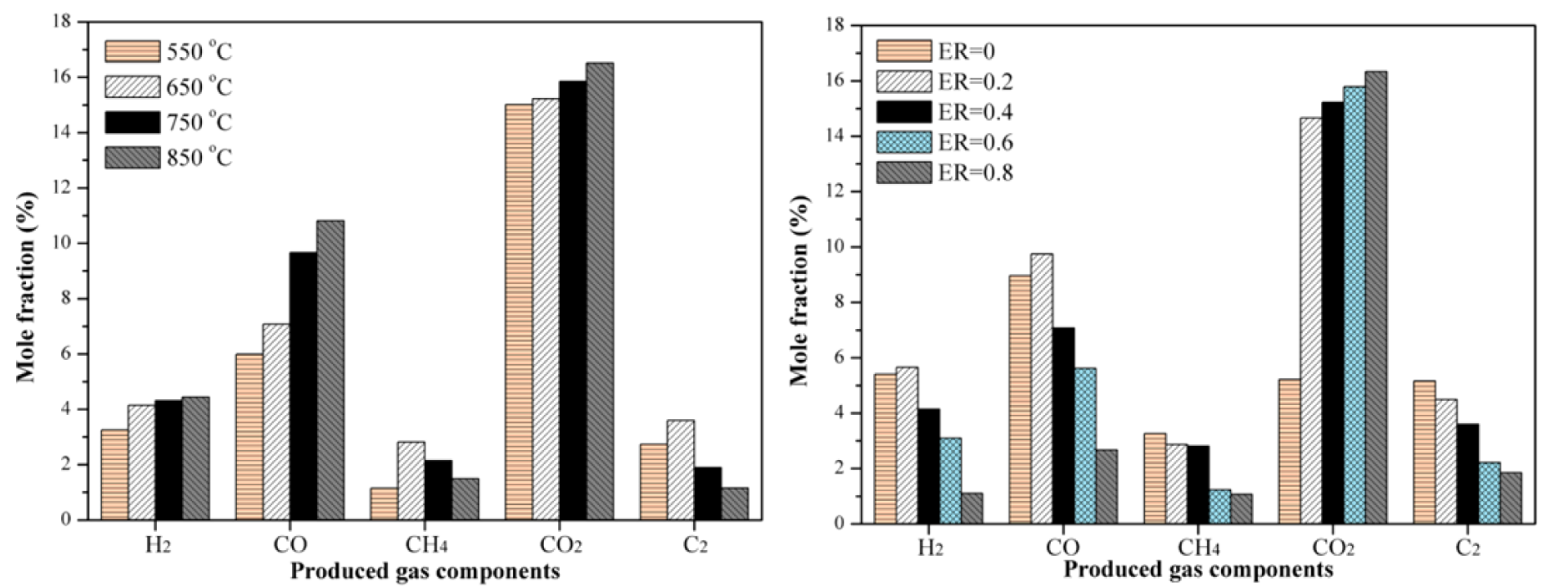

Figure 3. Effect of the temperature and ER on produced gas composition $\left(\mathrm{N}_{2}\right.$ and $\mathrm{O}_{2}$ are excluded; $\mathrm{C}_{2}$ represents the total amount of $\mathrm{C}_{2} \mathrm{H}_{6}, \mathrm{C}_{2} \mathrm{H}_{4}$, and $\mathrm{C}_{2} \mathrm{H}_{2}$ ).
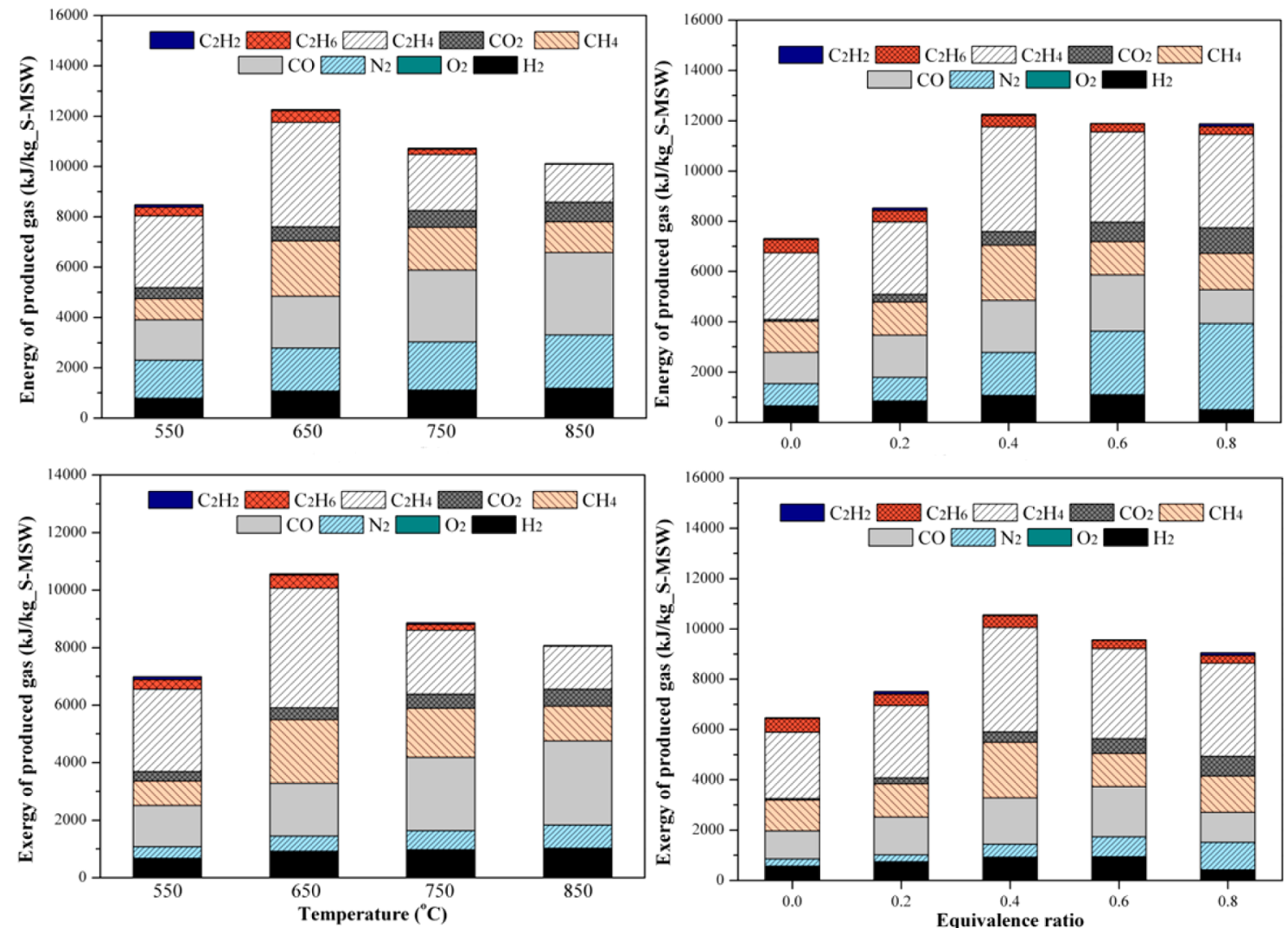

Figure 4. Effect of the temperature and ER on energy and exergy values of produced gas.

where $\mathrm{H}, \mathrm{C}$, and $\mathrm{O}$ are the molar fractions of hydrogen, carbon, and oxygen in liquid material, respectively.

2.3. Energy and Exergy Efficiencies. To assess the energy performance of S-MSW gasification, chemical energy and total energy efficiencies $^{28}$ are defined on the basis of the first law of thermodynamics and are defined by eqs 11 and 12

$$
\begin{aligned}
& \operatorname{ChEEf}(\%)=\frac{E_{\text {gas }}+E_{\text {tar }}+E_{\mathrm{fa}}}{E_{\mathrm{S}-\mathrm{MSW}}+E_{\text {agent }}} \times 100 \% \\
& \operatorname{ToEEf}(\%)=\frac{H_{\text {sensi }}+E_{\text {gas }}+E_{\text {tar }}+E_{\mathrm{fa}}}{E_{\mathrm{S}-\mathrm{MSW}}+E_{\text {agent }}} \times 100 \%
\end{aligned}
$$

where ChEEf and ToEEf represent the chemical energy efficiency and total energy efficiency, respectively, and are defined as the ratios of the chemical energy and total energy (chemical energy and sensible energy) contents of the products at the furnace exit to the total energy input, and $H_{\text {sensi }}$ stands for the total amount of sensible energy of produced gas, tar, fly ash, and water vapor at the furnace exit.

Chemical and total exergy efficiencies are defined as the ratios of the chemical exergy and total exergy of products at the furnace exit to the total exergy input and are described as

$$
\begin{aligned}
& \text { CheEf }=\frac{e_{\text {gas }}+e_{\text {tar }}+e_{\mathrm{fa}}}{e_{\mathrm{S}-\mathrm{MSW}}+\mathrm{e}_{\text {agent }}} \\
& \text { ToeEf }=\frac{e_{\mathrm{gas}}^{\text {tot }}+e_{\mathrm{tar}}^{\text {tot }}+e_{\mathrm{fa}}^{\text {tot }}+e_{\text {water }}^{\text {tot }}}{e_{\mathrm{S}-\mathrm{MSW}}+\mathrm{e}_{\text {agent }}}
\end{aligned}
$$


Table 3. Energy and Exergy Distributions of Gas Products

\begin{tabular}{|c|c|c|c|}
\hline ER & temperature $\left({ }^{\circ} \mathrm{C}\right)$ & energy distribution $^{a}$ & exergy distribution \\
\hline 0 & \multirow[t]{5}{*}{650} & $\mathrm{C}_{2} \mathrm{H}_{4}>\mathrm{CO}>\mathrm{CH}_{4}>\mathrm{N}_{2}>\mathrm{H}_{2}>\mathrm{C}_{2} \mathrm{H}_{6}>\mathrm{CO}_{2}>\mathrm{C}_{2} \mathrm{H}_{2}>\mathrm{O}_{2}$ & $\mathrm{C}_{2} \mathrm{H}_{4}>\mathrm{CH}_{4}>\mathrm{CO}>\mathrm{H}_{2}>\mathrm{C}_{2} \mathrm{H}_{6}>\mathrm{N}_{2}>\mathrm{CO}_{2}>\mathrm{C}_{2} \mathrm{H}_{2}>\mathrm{O}_{2}$ \\
\hline 0.2 & & $\mathrm{C}_{2} \mathrm{H}_{4}>\mathrm{CO}>\mathrm{CH}_{4}>\mathrm{N}_{2}>\mathrm{H}_{2}>\mathrm{C}_{2} \mathrm{H}_{6}>\mathrm{CO}_{2}>\mathrm{C}_{2} \mathrm{H}_{2}>\mathrm{O}_{2}$ & $\mathrm{C}_{2} \mathrm{H}_{4}>\mathrm{CO}>\mathrm{CH}_{4}>\mathrm{H}_{2}>\mathrm{C}_{2} \mathrm{H}_{6}>\mathrm{N}_{2}>\mathrm{CO}_{2}>\mathrm{C}_{2} \mathrm{H}_{2}>\mathrm{O}_{2}$ \\
\hline 0.4 & & $\mathrm{C}_{2} \mathrm{H}_{4}>\mathrm{CH}_{4}>\mathrm{CO}>\mathrm{N}_{2}>\mathrm{H}_{2}>\mathrm{CO}_{2}>\mathrm{C}_{2} \mathrm{H}_{6}>\mathrm{C}_{2} \mathrm{H}_{2}>\mathrm{O}_{2}$ & $\mathrm{C}_{2} \mathrm{H}_{4}>\mathrm{CH}_{4}>\mathrm{CO}>\mathrm{H}_{2}>\mathrm{N}_{2}>\mathrm{C}_{2} \mathrm{H}_{6}>\mathrm{CO}_{2}>\mathrm{C}_{2} \mathrm{H}_{2}>\mathrm{O}_{2}$ \\
\hline 0.6 & & $\mathrm{C}_{2} \mathrm{H}_{4}>\mathrm{N}_{2}>\mathrm{CO}>\mathrm{CH}_{4}>\mathrm{H}_{2}>\mathrm{CO}_{2}>\mathrm{C}_{2} \mathrm{H}_{6}>\mathrm{O}_{2}>\mathrm{C}_{2} \mathrm{H}_{2}$ & $\mathrm{C}_{2} \mathrm{H}_{4}>\mathrm{N}_{2}>\mathrm{CO}>\mathrm{CH}_{4}>\mathrm{H}_{2}>\mathrm{C}_{2} \mathrm{H}_{6}>\mathrm{CO}_{2}>\mathrm{C}_{2} \mathrm{H}_{2}>\mathrm{O}_{2}$ \\
\hline 0.8 & & $\mathrm{C}_{2} \mathrm{H}_{4}>\mathrm{N}_{2}>\mathrm{CH}_{4}>\mathrm{CO}>\mathrm{CO}_{2}>\mathrm{H}_{2}>\mathrm{C}_{2} \mathrm{H}_{6}>\mathrm{C}_{2} \mathrm{H}_{2}>\mathrm{O}_{2}$ & $\mathrm{C}_{2} \mathrm{H}_{4}>\mathrm{CH}_{4}>\mathrm{CO}>\mathrm{N}_{2}>\mathrm{CO}_{2}>\mathrm{H}_{2}>\mathrm{C}_{2} \mathrm{H}_{6}>\mathrm{C}_{2} \mathrm{H}_{2}>\mathrm{O}_{2}$ \\
\hline \multirow[t]{4}{*}{0.4} & 550 & $\mathrm{C}_{2} \mathrm{H}_{4}>\mathrm{CO}>\mathrm{N}_{2}>\mathrm{CH}_{4}>\mathrm{H}_{2}>\mathrm{CO}_{2}>\mathrm{C}_{2} \mathrm{H}_{6}>\mathrm{C}_{2} \mathrm{H}_{2}>\mathrm{O}_{2}$ & $\mathrm{C}_{2} \mathrm{H}_{4}>\mathrm{CO}>\mathrm{CH}_{4}>\mathrm{H}_{2}>\mathrm{N}_{2}>\mathrm{CO}_{2}>\mathrm{C}_{2} \mathrm{H}_{6}>\mathrm{C}_{2} \mathrm{H}_{2}>\mathrm{O}_{2}$ \\
\hline & 650 & $\mathrm{C}_{2} \mathrm{H}_{4}>\mathrm{CH}_{4}>\mathrm{CO}>\mathrm{N}_{2}>\mathrm{H}_{2}>\mathrm{CO}_{2}>\mathrm{C}_{2} \mathrm{H}_{6}>\mathrm{C}_{2} \mathrm{H}_{2}>\mathrm{O}_{2}$ & $\mathrm{C}_{2} \mathrm{H}_{4}>\mathrm{CH}_{4}>\mathrm{CO}>\mathrm{H}_{2}>\mathrm{N}_{2}>\mathrm{C}_{2} \mathrm{H}_{6}>\mathrm{CO}_{2}>\mathrm{C}_{2} \mathrm{H}_{2}>\mathrm{O}_{2}$ \\
\hline & 750 & $\mathrm{CO}>\mathrm{C}_{2} \mathrm{H}_{4}>\mathrm{N}_{2}>\mathrm{CH}_{4}>\mathrm{H}_{2}>\mathrm{CO}_{2}>\mathrm{C}_{2} \mathrm{H}_{6}>\mathrm{C}_{2} \mathrm{H}_{2}>\mathrm{O}_{2}$ & $\mathrm{CO}>\mathrm{C}_{2} \mathrm{H}_{4}>\mathrm{CH}_{4}>\mathrm{H}_{2}>\mathrm{N}_{2}>\mathrm{CO}_{2}>\mathrm{C}_{2} \mathrm{H}_{6}>\mathrm{C}_{2} \mathrm{H}_{2}>\mathrm{O}_{2}$ \\
\hline & 850 & $\mathrm{CO}>\mathrm{N}_{2}>\mathrm{C}_{2} \mathrm{H}_{4}>\mathrm{CH}_{4}>\mathrm{H}_{2}>\mathrm{CO}_{2}>\mathrm{O}_{2}>\mathrm{C}_{2} \mathrm{H}_{2}>\mathrm{C}_{2} \mathrm{H}_{6}$ & $\mathrm{CO}>\mathrm{C}_{2} \mathrm{H}_{4}>\mathrm{CH}_{4}>\mathrm{H}_{2}>\mathrm{N}_{2}>\mathrm{CO}_{2}>\mathrm{C}_{2} \mathrm{H}_{2}>\mathrm{O}_{2}>\mathrm{C}_{2} \mathrm{H}_{6}$ \\
\hline
\end{tabular}

a“>” means that the energy or exergy values of the former gas components are higher than that of the latter gas components.

Table 4. Effect of the ER and Temperature on Product Mass Distribution and Gas Yield

\begin{tabular}{|c|c|c|c|c|c|c|c|}
\hline \multirow[b]{2}{*}{$\mathrm{ER}^{b}$} & \multirow[b]{2}{*}{ temperature $\left({ }^{\circ} \mathrm{C}\right)$} & \multicolumn{5}{|c|}{ product mass distribution (wt $\%)^{a}$} & \multirow[b]{2}{*}{ gas yield $\left(\mathrm{N} \mathrm{m}^{3} \mathrm{~kg}^{-1}\right.$ of S-MSW) } \\
\hline & & produced gas & fly ash & $\operatorname{tar}$ & char & water & \\
\hline 0 & 650 & 64.14 & 0.92 & 11.04 & 11.94 & 3.45 & 1.11 \\
\hline 0.2 & & 70.68 & 0.63 & 6.32 & 9.24 & 3.19 & 1.37 \\
\hline 0.4 & & 83.63 & 0.51 & 2.19 & 5.48 & 2.49 & 2.32 \\
\hline 0.6 & & 87.45 & 0.36 & 1.36 & 3.60 & 1.92 & 3.18 \\
\hline 0.8 & & 88.42 & 0.35 & 0.58 & 2.27 & 1.68 & 4.01 \\
\hline \multirow[t]{4}{*}{0.4} & 550 & 79.36 & 0.34 & 2.78 & 8.67 & 2.15 & 2.17 \\
\hline & 650 & 83.63 & 0.51 & 2.19 & 5.48 & 2.49 & 2.32 \\
\hline & 750 & 84.35 & 0.65 & 1.78 & 5.53 & 2.68 & 2.33 \\
\hline & 850 & 86.03 & 0.53 & 1.52 & 4.07 & 2.86 & 2.37 \\
\hline
\end{tabular}

${ }^{a}$ Product mass distribution means the mass ratio of the specific product stream to the total input streams. ${ }^{b}$ ER is defined as the mole ratio of the air supplied to the furnace divided by the stoichiometric air required for complete combustion.

where CheEf and ToeEf represent the chemical exergy efficiency and total exergy efficiency of products at the furnace exit, respectively, $e_{\mathrm{tar}}^{\text {tot }}$, $e_{\mathrm{fa}}^{\text {tot }}$, and $e_{\mathrm{water}}^{\text {tot }}$ represent the total exergy contents of tar, fly ash, and water at the furnace exit, respectively.

\section{RESULTS AND DISCUSSION}

\subsection{Energy and Exergy Analyses of Produced Gas.}

Produced gas composition as a function of the temperature and ER is depicted in Figure 3. It is observed that the concentration of $\mathrm{H}_{2}$ and $\mathrm{CO}$ in the producer gas is effectively promoted by 11.51 and $47.70 \%$ when increasing the temperature from 550 to $850{ }^{\circ} \mathrm{C}$. This is mainly attributed to the enhanced endothermic reactions, such as steam reforming reaction $\left[\mathrm{C}_{n} \mathrm{H}_{m}+n \mathrm{H}_{2} \mathrm{O} \leftrightarrow\right.$ $\left.n \mathrm{CO}+(n+m / 2) \mathrm{H}_{2}\right]$ and water-gas shift reaction $\left(\mathrm{CO}+\mathrm{H}_{2} \mathrm{O}\right.$ $\leftrightarrow \mathrm{CO}_{2}+\mathrm{H}_{2}$ ) according to Le Chatelier's principle. ${ }^{29}$ Nevertheless, increasing the temperature from 650 to $850{ }^{\circ} \mathrm{C}$ causes the sustained decrease in $\mathrm{CH}_{4}$ and $\mathrm{C}_{2}$ hydrocarbon yields, resulting in the decrease of produced gas energy content. As for ERs, the mole fraction of the combustible gases shows an obvious decrease: $\mathrm{H}_{2}$ is declined from 19.20 to $4.80 \%$; $\mathrm{CO}$ is declined from 32.03 to $11.62 \% ; \mathrm{CH}_{4}$ is declined from 11.64 to $4.64 \%$; and $\mathrm{C}_{2}$ hydrocarbons are declined from 18.41 to $8.02 \%$, when ER is increased from 0 to 0.8 . This is mainly caused by the strengthened oxidation reactions, because more oxygen is available at higher ER values. On the contrary, the $\mathrm{CO}_{2}$ concentration increases continuously from 18.63 to $70.91 \%$ in the entire range of ERs as a result of the enhanced partial combustion. $^{8}$

The energy content of the produced gas as a function of the temperature and ER is shown in Figure 4. The peak value of produced gas energy content is observed at a temperature of $650{ }^{\circ} \mathrm{C}$ and an ER of 0.4 . The total energy content of the produced gas increases when increasing the ER from 0 to 0.4 and then decreases slightly with the ER further increasing. The initial growth of produced gas quality can be explained because more combustible gases (i.e., $\mathrm{CO}, \mathrm{C}_{2} \mathrm{H}_{4}$, and $\mathrm{H}_{2}$ ) are produced. However, at higher ERs, the reactions in the furnace are gradually converted from gasification to combustion. ${ }^{30}$ Combustible gases are the main contributor to energy values, accounting for approximately $62-87 \%$ at all conditions. The rest is shared by the sensible energy of incombustible components $\left(\mathrm{N}_{2}\right.$ and $\left.\mathrm{CO}_{2}\right)$. The energy distribution of produced gas components with the temperature and $\mathrm{ER}$ is summarized in Table 3. Accordingly, $\mathrm{C}_{2} \mathrm{H}_{4}$ is the most important energy carrier of gas under most working conditions, whereas $\mathrm{C}_{2} \mathrm{H}_{2}$ and $\mathrm{O}_{2}$ rank last. The overall distribution of $\mathrm{C}_{2} \mathrm{H}_{4}>\left(\mathrm{CO}, \mathrm{CH}_{4}\right.$, and $\left.\mathrm{N}_{2}\right)>\left(\mathrm{H}_{2}, \mathrm{C}_{2} \mathrm{H}_{6}\right.$, and $\left.\mathrm{CO}_{2}\right)>\left(\mathrm{C}_{2} \mathrm{H}_{2}\right.$ and $\left.\mathrm{O}_{2}\right)$ is observed under the entire range of ERs, while under different temperatures, the distribution of $\left(\mathrm{C}_{2} \mathrm{H}_{4}, \mathrm{CO}, \mathrm{N}_{2}\right.$, and $\left.\mathrm{CH}_{4}\right)>\left(\mathrm{H}_{2}\right.$ and $\left.\mathrm{CO}_{2}\right)>\left(\mathrm{C}_{2} \mathrm{H}_{6}, \mathrm{C}_{2} \mathrm{H}_{2}\right.$, and $\left.\mathrm{O}_{2}\right)$ is obtained. The gas components at the forefront in the present work $\left(\mathrm{C}_{2} \mathrm{H}_{4}, \mathrm{CO}\right.$, and $\left.\mathrm{CH}_{4}\right)$ are mainly attributed to the relatively high yields and LHV. In addition, it is also worth mentioning that, at higher ER values, sensible energy of $\mathrm{N}_{2}$ and $\mathrm{CO}_{2}$ also accounts for a high proportion as a result of the considerable increasing amount in the produced gas.

Figure 4 also presents the exergy values of produced gas as a function of the temperature and ER. The total exergy content of the produced gas ranges from 6475.05 to $10567.51 \mathrm{~kJ} / \mathrm{kg}$ of S-MSW. Similar changed tendency of exergy contents with the temperature and ER has been observed in comparison to energy analysis. Nevertheless, the exergy content of gas species is much lower than the corresponding energy values, because exergy is defined aforementioned as the available part of energy. As discussed previously, the most obvious difference between energy and exergy analyses appears to be the physical energy 

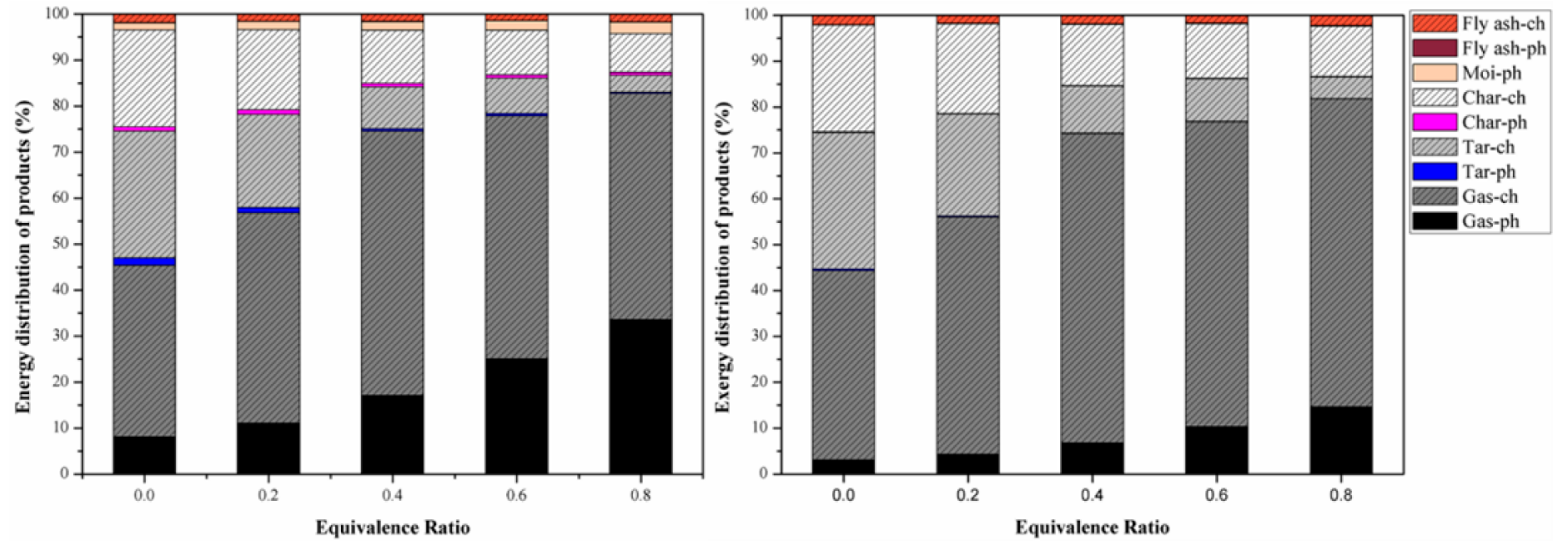

Figure 5. Physical and chemical energy/exergy distributions of the products (ph and ch represent for physical energy/exergy and chemical energy/ exergy, respectively).
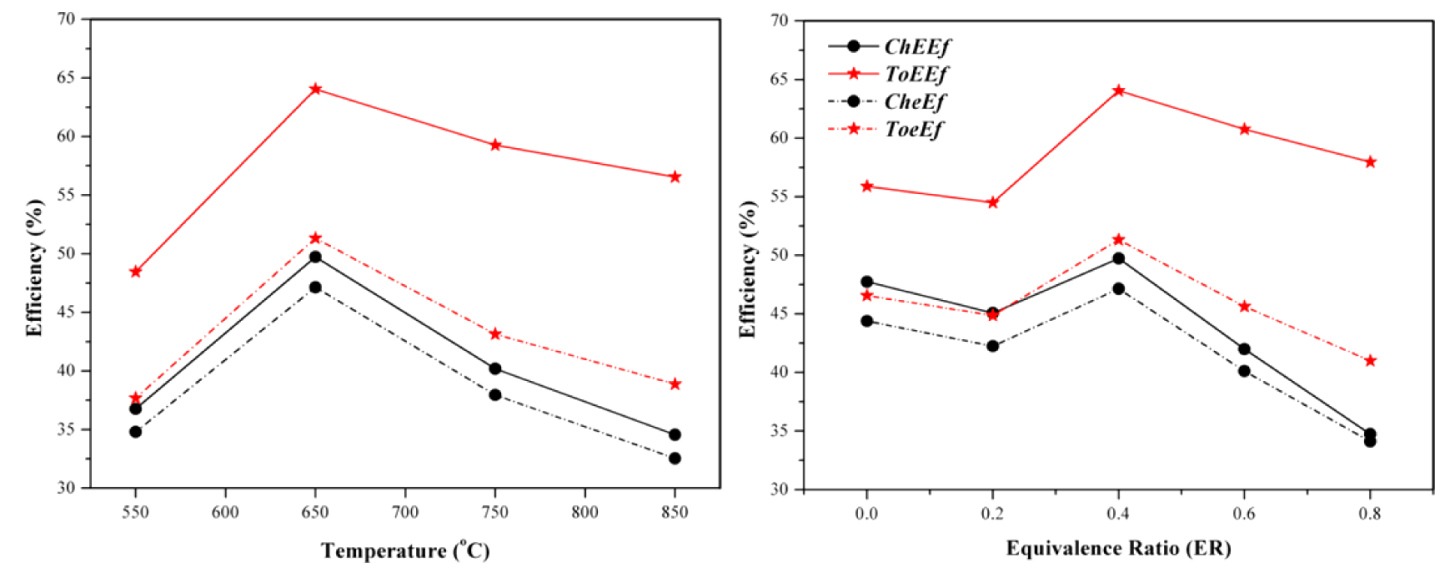

Figure 6. Effect of the temperature and ER on ChEEf, ToEEf, CheEf, and ToeEf of the products at the furnace exit.

and exergy values of sensible heat, especially for incombustible gas species, such as $\mathrm{N}_{2}$ and $\mathrm{CO}_{2}$, because sensible energy degrades significantly in exergy analysis. With the realization of this fact, the exergy of combustible gases occupies a much higher proportion (approximately 83-95\%) in the total exergy of the produced gas. The overall exergy distribution of $\left(\mathrm{C}_{2} \mathrm{H}_{4}\right.$, $\mathrm{CH}_{4}$, and $\left.\mathrm{CO}\right)>\left(\mathrm{H}_{2}, \mathrm{C}_{2} \mathrm{H}_{6}, \mathrm{~N}_{2}\right.$, and $\left.\mathrm{CO}_{2}\right)>\left(\mathrm{C}_{2} \mathrm{H}_{2}\right.$ and $\left.\mathrm{O}_{2}\right)$ is obtained (Table 3 ).

3.2. Energy and Exergy of Gasification Products. Table 4 lists the mass distribution and producer gas yield under varied temperatures $\left(550-850{ }^{\circ} \mathrm{C}\right)$ and ERs $(0-0.8)$. For all experimental runs, the closure of the mass balance is between 89 and $96 \%$, which is under the acceptable level. ${ }^{31}$ Mass distribution of produced gas increases sharply with increasing temperatures and ERs. The gas yield rises from $1.11 \mathrm{~N} \mathrm{~m}^{3} \mathrm{~kg}^{-1}$ of S-MSW (ER $=0$ and temperature $=550{ }^{\circ} \mathrm{C}$ ) to $4.01 \mathrm{~N} \mathrm{~m}^{3}$ $\mathrm{kg}^{-1}$ of S-MSW (ER $=0.8$ and temperature $=850{ }^{\circ} \mathrm{C}$ ). Meanwhile, the mass distribution of char and tar is dramatically decreased by approximately 86 and $95 \%$ as ER increases. A 53 and $45 \%$ reduction of tar and char, respectively, is also observed when increasing the temperature from 550 to $850{ }^{\circ} \mathrm{C}$. It could be attributed to either greater oxidization reactions or the enhanced secondary decomposition/reforming reactions of char and tar at a higher temperature and ER. The results are in good accordance with previous findings. ${ }^{32}$

The physical and chemical energy/exergy distributions of product streams as a function of the ER are exhibited in Figure 5. It is shown that the energy content of the produced gas takes a leading part of the total energy content of the products, especially at higher ER values. This is mainly due to the sharp rise in the gas yield with increasing the ER. On the contrary, the energy content of the tar and char decreases continuously with the ER. For the entire range of the ER, the energy distributed in the produced gas varies from 45.35 to $82.75 \%$; while that value is from 29.21 to $3.98 \%$ and from 22.01 to $9.06 \%$ for tar and char, respectively. Meanwhile, it is notable that, even at the ER of 0.8 , the chemical and physical energy contents of char are 1.49 and $0.11 \mathrm{MJ} / \mathrm{kg}$ of S-MSW, respectively, indicating that the complete char gasification is not achieved under tested working conditions as a result of the fact that the experiments are conducted in a lab-scale facility. However, we think that the results are reasonable, and a similar phenomenon has been reported by other studies. ${ }^{25,33}$

With regard to exergy analysis, a similar tendency of exergy distribution is observed. The exergy distributed in produced gas varies from 44.35 to $81.79 \%$, while it varies from 30.10 to $4.75 \%$ and from 23.43 to $12.08 \%$ for tar and char, respectively. However, in comparison to the energy distribution, it is found that physical exergy of products occupies a much lower proportion in the total exergy content, accounting for only $3.73-15.04 \%$ in the entire ER range, and the proportion rises slightly with increasing the ER. This mainly resulted from the difference between energy and exergy analyses, because the physical energy content of products is much higher than the physical exergy values as a result of the Carnot efficiency. ${ }^{34}$ 
3.3. Energy and Exergy Efficiencies. Figure 6 depicts the chemical energy efficiency, total energy efficiency, chemical exergy efficiency, and total exergy efficiency of the products at the furnace exit with varied temperatures and ERs. Results reveal that ChEEf, ToEEf, CheEf, and ToeEf vary in the range of $34.56-49.73,48.46-64.05,32.54-47.14$, and 37.69$51.33 \%$, respectively. A similar changed tendency of the efficiencies is observed from an energy and exergy analysis perspective. The peak value of the efficiencies appears at ER of 0.4 and temperature of $650{ }^{\circ} \mathrm{C}$. When increasing the temperature from 550 to $650{ }^{\circ} \mathrm{C}$, ChEEf, ToEEf, CheEf, and ToeEf are improved by $12.96,16.58,12.33$, and $13.64 \%$, respectively. Nevertheless, the further increase of the gasification temperature to $850{ }^{\circ} \mathrm{C}$ significantly reduces the efficiencies to $34.56,56.55,32.54$, and $38.66 \%$, respectively. The drop in the yield of $\mathrm{C}_{2}$ hydrocarbons and $\mathrm{CH}_{4}$ (as shown in Figure 3) is responsible for the decrease, because $\mathrm{C}_{2} \mathrm{H}_{4}$ and $\mathrm{CH}_{4}$ are the most important energy and exergy carriers in the producer gas as aforementioned. The results agree well with the theoretical prediction work conducted by Karamarkovic and Karamarkovic, ${ }^{35}$ indicating that, during biomass gasification, efficiencies based on the chemical energy, chemical exergy, and total (chemical and physical) exergy of produced gas decrease when increasing the temperature from 963 to $1373 \mathrm{~K}$. With regard to ER, it is notable that the efficiencies are declined when increasing the ER from 0 to 0.2 . This is mainly attributed to the additional heat supply during pyrolysis $(\mathrm{ER}=0)$, because pyrolysis is an endothermic process. However, as discussed previously, this part of energy is not taken into account as energy input as a result of measurement limitations, which leads to overestimations of the efficiencies at the ER of 0 , because according to Baggio et al., ${ }^{36}$ approximately $9 \%$ of the MSW high heating value energy is required to maintain pyrolysis at $500{ }^{\circ} \mathrm{C}$. Despite pyrolysis working conditions, all of the efficiencies are increased at first and decreased afterward with peak values at the ER of 0.4. The initial growth is mainly attributed to the enhanced gasification reactions as a result of a sufficient oxygen supply, while with a further increase of the ER, overoxidation of combustible gas products occurs. Peak values of ChEEf, ToEEf, CheEf, and ToeEf reach 49.73, 64.05, 47.14 , and $51.33 \%$, respectively.

Energy loss during the experiments is unavoidable and may result from several possibilities, such as incomplete conversion and heat loss. Consequently, obtained ChEEf, ToEEf, CheEf, and ToeEf of the products at the furnace exit are not as high as commercial operation results. ${ }^{37}$ It is mainly attributed to the lab-scale experimental setup used in this study, in which the amount of unconverted carbon in the furnace is increased as a result of kinetic limitations ${ }^{35}$ and the heat loss from the reactor to the surroundings during the experiments is strengthened. ${ }^{38,39}$ However, the results are acceptable, because similar efficiencies on small-scale facility experiments are also obtained by Thamavithya and Dutta ${ }^{8}$ and Carpenter et al. ${ }^{40}$

Besides, it is notable that the differences between energy and exergy efficiencies are more remarkable at higher temperatures and ERs (see Figure 6). This phenomenon is mainly attributed to the enhanced heat transfer and chemical reactions, which will cause considerable internal destruction of available energy (i.e., irreversibility). Therefore, measures should be taken to lower the internal exergy destruction of the irreversible gasification process. For instance, the primary air can be preheated by waste heat before supplying into the gasifier to reduce energy depletion caused by heat transfer. Also, an ER value of gasification needs to be balanced on the basis of produced gas quality, gas yield, and process irreversibility.

3.4. Comparisons and Recommendations. Using both energy and exergy analyses, thermodynamic properties of input and output streams are calculated and compared, to better reflect the performance of gasification-based systems. On the basis of the calculation, the comparison between energy and exergy methods are discussed.

As evident from the present work, the exergy efficiencies are lower than their counterpart energy efficiencies. Generally, the efficiencies analyzed in descending order are ToEEf, ToeEf, ChEEf, and CheEf. The total energy efficiency (ToEEf) exhibits the highest value among all of the efficiencies, because it considers the total amount of chemical and physical energies of gasification products. Meanwhile, the ChEEf and CheEf values are found to be extremely similar. This is mainly because the chemical energy and chemical exergy contents of the products are similar, given the fact that they are both calculated on the basis of the lower heating value. On the contrary, ToEEf and ToeEf show a significant gap, indicating that the total energy and exergy contents of products differ a lot, mainly attributed to the difference between physical energy and physical exergy contents of the products, as stated previously.

To summarize, it can be concluded that the total energy efficiency (ToEEf) is not sufficient enough to evaluate the properties of gasification-based "two-step" conversion systems, because ToEEf takes into account only the energy quantity of the products from the gasifier but ignores the energy quality (or the available energy). Therefore, even at high ERs, the ToEEf value is also high. However, for gasification-based systems, the available energy of the products from the "first-step" gasifier directly determines the efficiency of the subsequent "secondstep" utilization process (usually secondary combustion chamber, gas turbine, internal combustion engine, etc.). The chemical energy efficiency (ChEEf or cold gas efficiency with special regard to produced gas) is more reasonable for gasification conversions; however, when it is applied to assess "two-step combustion", the sensible energy content of the products exiting the furnace should not be overlooked. It follows that the total exergy efficiency (ToeEf), which considers the available energy of the products from the gasifier as aforementioned in section 2.3, is suggested as a more preferable parameter to evaluate the thermodynamic performance of gasification-based "two-step" waste to energy conversion systems, because it takes into account the quality of both chemical and physical energies for the downstream "secondstep" conversion.

\section{CONCLUSION}

S-MSW gasification under a series of temperatures and ERs is experimentally investigated in the present work. Results reveal that the yield of produced gas rises continuously with increasing the ER and temperature, while an opposite tendency is observed for tar and char. A higher temperature promotes the generation of $\mathrm{H}_{2}$ and $\mathrm{CO}$, but the fraction of combustible $\left(\mathrm{C}_{2} \mathrm{H}_{4}, \mathrm{CH}_{4}, \mathrm{CO}\right.$, and $\left.\mathrm{H}_{2}\right)$ gases decreases when the ER increases from 0 to 0.8 . Besides, this study also focuses on the thermodynamic performance of the gasification system by energy and exergy analyses. It is found that the energy and exergy contents of the produced gas occupies the majority proportion of the total product streams, especially at higher temperature and ER values. Combustible gases are the most dominant energy and exergy carriers, with $\mathrm{C}_{2} \mathrm{H}_{4}$ ranking first 
for most working conditions. The overall energy content distribution of $\left(\mathrm{C}_{2} \mathrm{H}_{4}, \mathrm{CO}, \mathrm{N}_{2}\right.$, and $\left.\mathrm{CH}_{4}\right)>\left(\mathrm{H}_{2}, \mathrm{CO}_{2}\right.$, and $\left.\mathrm{C}_{2} \mathrm{H}_{6}\right)>\left(\mathrm{C}_{2} \mathrm{H}_{2}\right.$ and $\left.\mathrm{O}_{2}\right)$ and exergy content distribution of $\left(\mathrm{C}_{2} \mathrm{H}_{4}, \mathrm{CO}\right.$, and $\left.\mathrm{CH}_{4}\right)>\left(\mathrm{H}_{2}, \mathrm{C}_{2} \mathrm{H}_{6}, \mathrm{~N}_{2}\right.$, and $\left.\mathrm{CO}_{2}\right)>\left(\mathrm{C}_{2} \mathrm{H}_{2}\right.$ and $\left.\mathrm{O}_{2}\right)$ are observed under all of the tests. With regard to efficiencies, the maximum chemical energy efficiency (ChEEf), total energy efficiency (ToEEf), chemical exergy efficiency (CheEf), and total exergy efficiency (ToeEf) are achieved at an ER of 0.4 and a temperature of $650{ }^{\circ} \mathrm{C}$ and the peak values are $49.73,64.05,47.14$, and $51.33 \%$, respectively. The total exergy efficiency (ToeEf) is suggested as a more preferable parameter to reflect gasification systems, because it evaluates the available energy of the products from the "first-step" gasifier for subsequent use.

\section{AUTHOR INFORMATION}

\section{Corresponding Author}

*Telephone: +86-0571-87952687. Fax: +86-0571-87952438. Email: chiyong@zju.edu.cn.

\section{Notes}

The authors declare no competing financial interest.

\section{ACKNOWLEDGMENTS}

This project is supported by the National Natural Science Foundation of China (51276168) and the Program of Introducing Talents of Discipline to University (B08026).

\section{REFERENCES}

(1) Kwak, T.-H.; Maken, S.; Lee, S.; Park, J.-W.; Min, B.-r.; Yoo, Y. D. Environmental aspects of gasification of Korean municipal solid waste in a pilot plant. Fuel 2006, 85 (14), 2012-2017.

(2) Dong, J.; Chi, Y.; Zou, D.; Fu, C.; Huang, Q.; Ni, M. Comparison of municipal solid waste treatment technologies from a life cycle perspective in China. Waste Manage. Res. 2014, 32 (1), 13-23.

(3) Harris, E.; Zeyer, K.; Kegel, R.; Müller, B.; Emmenegger, L.; Mohn, J. Nitrous oxide and methane emissions and nitrous oxide isotopic composition from waste incineration in Switzerland. Waste Manage. 2015, 35, 135-140.

(4) Arena, U.; Di Gregorio, F. Element partitioning in combustionand gasification-based waste-to-energy units. Waste Manage. 2013, 33 (5), 1142-1150.

(5) Li, H.; Nitivattananon, V.; Li, P. Municipal solid waste management health risk assessment from air emissions for China by applying life cycle analysis. Waste Manage. Res. 2015, 33 (5), 401-409.

(6) Ionescu, G.; Rada, E. C.; Ragazzi, M.; Mărculescu, C.; Badea, A.; Apostol, T. Integrated municipal solid waste scenario model using advanced pretreatment and waste to energy processes. Energy Convers. Manage. 2013, 76, 1083-1092.

(7) Xiao, G.; Jin, B.-s.; Zhong, Z.-p.; Chi, Y.; Ni, M.-j.; Cen, K.-f.; Xiao, R.; Huang, Y.-j.; Huang, H. Experimental study on MSW gasification and melting technology. J. Environ. Sci. 2007, 19 (11), $1398-1403$.

(8) Thamavithya, M.; Dutta, A. An investigation of MSW gasification in a spout-fluid bed reactor. Fuel Process. Technol. 2008, 89 (10), 949957.

(9) Chen, C.; Jin, Y.-Q.; Yan, J.-H.; Chi, Y. Simulation of municipal solid waste gasification in two different types of fixed bed reactors. Fuel 2013, 103, 58-63.

(10) Zheng, X.; Chen, C.; Ying, Z.; Wang, B. Experimental study on gasification performance of bamboo and $\mathrm{PE}$ from municipal solid waste in a bench-scale fixed bed reactor. Energy Convers. Manage. 2016, $117,393-399$

(11) Xiao, G.; Ni, M.-j.; Chi, Y.; Jin, B.-s.; Xiao, R.; Zhong, Z.-p.; Huang, Y.-j. Gasification characteristics of MSW and an ANN prediction model. Waste Manage. 2009, 29 (1), 240-244.
(12) Dincer, I. The role of exergy in energy policy making. Energy Policy 2002, 30 (2), 137-149.

(13) Strušnik, D.; Avsec, J. Artificial neural networking model of energy and exergy district heating mony flows. Energy and Buildings 2015, 86, 366-375.

(14) Orhan, M. F.; Dincer, I.; Rosen, M. A. An exergy-costenergy-mass analysis of a hybrid copper-chlorine thermochemical cycle for hydrogen production. Int. J. Hydrogen Energy 2010, 35 (10), 4831-4838.

(15) Luo, Y.; Wang, X. Exergy analysis on throttle reduction efficiency based on real gas equations. Energy 2010, 35 (1), 181-187.

(16) Aviara, N. A.; Onuoha, L. N.; Falola, O. E.; Igbeka, J. C. Energy and exergy analyses of native cassava starch drying in a tray dryer. Energy 2014, 73, 809-817.

(17) Wall, G.; Gong, M. On exergy and sustainable developmentPart 1: Conditions and concepts. Exergy, An International Journal 2001, 1 (3), 128-145.

(18) Pellegrini, L. F.; de Oliveira, S., Jr. Exergy analysis of sugarcane bagasse gasification. Energy 2007, 32 (4), 314-327.

(19) Kaushik, S.; Reddy, V. S.; Tyagi, S. Energy and exergy analyses of thermal power plants: A review. Renewable Sustainable Energy Rev. 2011, 15 (4), 1857-1872.

(20) Wu, Y.; Yang, W.; Blasiak, W. Energy and exergy analysis of high temperature agent gasification of biomass. Energies 2014, 7 (4), $2107-$ 2122.

(21) Zhang, Y.; Zhao, Y.; Gao, X.; Li, B.; Huang, J. Energy and exergy analyses of syngas produced from rice husk gasification in an entrained flow reactor. J. Cleaner Prod. 2015, 95, 273-280.

(22) Dong, J.; Ni, M.; Chi, Y.; Zou, D.; Fu, C. Life cycle and economic assessment of source-separated MSW collection with regard to greenhouse gas emissions: A case study in China. Environ. Sci. Pollut. Res. 2013, 20 (8), 5512-5524.

(23) Dong, J.; Chi, Y.; Tang, Y.; Ni, M.; Nzihou, A.; Weiss-Hortala, E.; Huang, Q. Partitioning of Heavy Metals in Municipal Solid Waste Pyrolysis, Gasification, and Incineration. Energy Fuels 2015, 29 (11), $7516-7525$.

(24) Morris, D. R.; Szargut, J. Standard chemical exergy of some elements and compounds on the planet earth. Energy 1986, 11 (8), $733-755$.

(25) Zhang, Y.; Li, B.; Li, H.; Zhang, B. Exergy analysis of biomass utilization via steam gasification and partial oxidation. Thermochim. Acta 2012, 538, 21-28.

(26) Linstrom, P.; Mallard, W. NIST Chemistry WebBook, NIST Standard Reference Database Number 69; National Institute of Standards and Technology (NIST): Gaithersburg, MD, 2010.

(27) Prins, M.; Ptasinski, K.; Janssen, F. Thermodynamics of gas-char reactions: First and second law analysis. Chem. Eng. Sci. 2003, 58 (3), $1003-1011$.

(28) Arena, U. Process and technological aspects of municipal solid waste gasification. A review. Waste Manage. 2012, 32 (4), 625-639.

(29) Yan, F.; Luo, S.-y.; Hu, Z.-q.; Xiao, B.; Cheng, G. Hydrogen-rich gas production by steam gasification of char from biomass fast pyrolysis in a fixed-bed reactor: Influence of temperature and steam on hydrogen yield and syngas composition. Bioresour. Technol. 2010, 101 (14), 5633-5637.

(30) Werle, S. Impact of feedstock properties and operating conditions on sewage sludge gasification in a fixed bed gasifier. Waste Manage. Res. 2014, 32 (10), 954-960.

(31) Shuai, C.; Hu, S.; He, L.; Xiang, J.; Sun, L.; Su, S.; Jiang, L.; Chen, Q.; Xu, C. The synergistic effect of $\mathrm{Ca}(\mathrm{OH}) 2$ on the process of lignite steam gasification to produce hydrogen-rich gas. Int. J. Hydrogen Energy 2014, 39 (28), 15506-15516.

(32) Wang, R.; Huang, Q.; Lu, P.; Li, W.; Wang, S.; Chi, Y.; Yan, J. Experimental study on air/steam gasification of leather scraps using Utype catalytic gasification for producing hydrogen-enriched syngas. Int. J. Hydrogen Energy 2015, 40 (26), 8322-8329.

(33) Chun, Y. N.; Ji, D. W.; Yoshikawa, K. Pyrolysis and gasification characterization of sewage sludge for high quality gas and char 
production. Journal of Mechanical Science and Technology 2013, 27 (1), 263-272.

(34) Panopoulos, K.; Fryda, L.; Karl, J.; Poulou, S.; Kakaras, E. High temperature solid oxide fuel cell integrated with novel allothermal biomass gasification: Part II: Exergy analysis. J. Power Sources 2006, 159 (1), 586-594.

(35) Karamarkovic, R.; Karamarkovic, V. Energy and exergy analysis of biomass gasification at different temperatures. Energy 2010, 35 (2), 537-549.

(36) Baggio, P.; Baratieri, M.; Gasparella, A.; Longo, G. A. Energy and environmental analysis of an innovative system based on municipal solid waste (MSW) pyrolysis and combined cycle. Appl. Therm. Eng. 2008, 28 (2), 136-144.

(37) Tanigaki, N.; Manako, K.; Osada, M. Co-gasification of municipal solid waste and material recovery in a large-scale gasification and melting system. Waste Manage. 2012, 32 (4), 667-675.

(38) Pérez, J. F.; Benjumea, P. N.; Melgar, A. Sensitivity analysis of a biomass gasification model in fixed bed downdraft reactors: Effect of model and process parameters on reaction front. Biomass Bioenergy 2015, 83, 403-421.

(39) Wiinikka, H.; Johansson, A.-C.; Wennebro, J.; Carlsson, P.; Öhrman, O. G. Evaluation of black liquor gasification intended for synthetic fuel or power production. Fuel Process. Technol. 2015, 139, 216-225.

(40) Carpenter, D. L.; Bain, R. L.; Davis, R. E.; Dutta, A.; Feik, C. J.; Gaston, K. R.; Jablonski, W.; Phillips, S. D.; Nimlos, M. R. Pilot-scale gasification of corn stover, switchgrass, wheat straw, and wood: 1 . Parametric study and comparison with literature. Ind. Eng. Chem. Res. 2010, 49 (4), 1859-1871.

(41) Haynes, W. M. CRC Handbook of Chemistry and Physics; CRC Press: Boca Raton, FL, 2014. 